\title{
SISTEM PENDUKUNG KEPUTUSAN PEMILIHAN PROGRAM STUDI PERGURUAN TINGGI MENGGUNAKAN METODE PROFILE MATCHING PADA SMA N 13 PALEMBANG
}

\author{
Septia Monita ${ }^{1}$, Leon Andretti Abdillah ${ }^{2 *}$, Eka Puji Agustini ${ }^{3}$ \\ ${ }^{1,2,3}$ Program Studi Sistem Informasi, Universitas Bina Darma \\ ${ }_{1,2,3}$ Jalan Ahmad Yani No.3, Plaju, Palembang \\ ${ }^{1}$ septiamonita18@gmail.com, ${ }^{2 *}$ leon.abdillah@yahoo.com
}

\begin{abstract}
SMA Negeri 13 Palembang is one of the state schools that aims to produce graduates who are competent in accordance with their fields, talents and interests. In the process of choosing a study program to enter the university invitation path at high school $N 13$ Palembang, the value of the report card and achievements obtained is a requirement to enter the college invitation path. The students are faced with a variety of considerations and choices are quite complicated. Considerations from the students themselves such as the field of study is mastered, student interests, ideals, achievements, values, academic and social environment while considerations that come from the parents such as education costs and expectations of parents against their children. Various considerations that make students who make decisions in choosing college feelings, invitation of friends and ambitions of parents only, but it can not be used as a proper reply ukaut. Based on these problems then made a decision support system using the method of profile matching that can help students and the school in choosing a study program in accordance with the desired criteria. The design of this decision support system using prototype as a method of developing the system and PHP and MySQL as programming languages.
\end{abstract}

Keywords: DSS, Profile Matching, Study Program Selection, SMA N 13 Palembang.

\section{PENDAHULUAN}

Penggunaan komputer telah berkembang, dari sekedar pengolahan data ataupun penyajian informasi menjadi mampu untuk menyediakan pilihan sebagai pendukung pengambilan keputusan yang dapat dilakukan oleh manajemen. Hal tersebut dimungkinkan berkat adanya perkembangan teknologi perangkat keras, yang diiringi oleh perkembangan perangkat lunak dan proses keputusan didalamnya. Integrasi dari perangkat keras, perangkat lunak dan proses keputusan tersebut menghasilkan sistem pendukung keputusan (SPK) yang memungkinkan pengguna untuk melakukan pengambilan keputusan dengan lebih cepat dan cermat.

SPK atau Decision Support System (DSS) adalah bagian dari sistem informasi berbasis komputer yang dipakai untuk mendukung pengambilan keputusan dalam suatu organisasi atau perusahaan (Putra, Abdillah, \& Yudiastuti, 2016) baik untuk jangka pendek, menengah, ataupun panjang (Umami, Abdillah, \& Yadi, 2014). Lebih lanjut SPK adalah suatu sistem informasi berbasis komputer yang menghasilkan berbagai alternatif keputusan untuk membantu manajemen dalam menangani berbagai masalah yang memerlukan penilaian atau judgement dari pengambil keputusan dengan menggunakan data dan model (Surbakti, 2002). Penerapan SPK telah banyak dilakukan pada berbagai aktifitas bisnis, baik itu untuk memudahkan aktifitas bisnis penjualan, penilaian kinerja dan pendidikan. SPK merupakan salah satu bagian dari sistem informasi yang berguna untuk meningkatkan efektifitas pengambilan keputusan (Murti, Abdillah, \& Sobri, 2015). Permasalahan yang umum dijadikan objek pada SPK ada yang bersifat terstruktur dan tidak terstruktur. Permasalahan terstruktur berarti permasalahan rutin yang sering terjadi berulang-ulang, dan biasanya ada prosedur standar untuk menyelesaikannya. Sedangkan permasalahan semi terstruktur tidak mempunyai fase fase yang jelas dan terdefinisi. Ada beberapa metode yang sering digunakan dalam pemodelan SPK (Ariani, Abdillah, \& Syakti, 2013) antara lain adalah Analytical Hierarchy Process (AHP), Technique For Order Preference By Similarity To Ideal Solution (TOPSIS), dan Fuzzy Multiple Attribute Decision Making (FMADM). Namun pada penelitian ini penulis akan menggunakan metode Profile Matching dalam membuat SPK ini. Profile matching atau pencocokan profil adalah metode yang sering digunakan sebagai mekanisme dalam pengambilan keputusan dengan mengasumsikan bahwa terdapat tingkat variable predictor yang ideal yang harus dipenuhi oleh subyek yang diteliti, bukannya tingkat minimal yang harus dipenuhi atau dilewati (Kusrini, 2007). Dalam proses 
profile matching secara garis besar merupakan proses membandingkan antara kompetensi setiap program studi ke dalam kompetensi siswa sehingga dapat diketahui perbedaan kompetensinya ( $\mathrm{gap}$ ), semakin kecil gap yang dihasilkan maka bobot nilainya semakin besar yang berarti memiliki peluang lebih besar untuk prioritas program studi tertentu diberikan kepada seorang siswa. SPK pemilihan program studi merupakan salah satu sistem yang dapat membantu Guru BK untuk mengetahui siswa yang akan menempuh studi lanjut (Nufus, 2013).

SMA Negeri 13 Palembang merupakan salah satu wadah pendidikan dan memiliki 2 (dua) jurusan yang diantaranya Ilmu Pengetahuan Alam (IPA) dan Ilmu Pengetahuan Sosial (IPS). Tujuan pihak SMA Negeri 13 Palembang yaitu menghasilkan lulusan yang kompeten sesuai dengan bidang, bakat dan minatnya. Dalam proses pemilihan program studi untuk masuk perguruan tinggi jalur undangan pada sekolah SMA N 13 Palembang, nilai rapor dan prestasi yang didapat merupakan syarat masuk perguruan tinggi jalur undangan. Pada saat seleksi, pihak sekolah hanya mempersiapkan data yang diperlukan, informasi tentang data apa saja yang diperlukan tidak akan dikasih tahu oleh panitia jalur undangan. Tetapi, kriteria penilaian pada saat wawancara akan menentukan nilai sebenarnya dari masing-masing siswa/siswa pilihan.

Persoalan pengambilan keputusan, pada dasarnya adalah bentuk pemilihan dari berbagai alternatif tindakan yang mungkin dipilih yang mungkin dipilih yang prosesnya melalui mekanisme tertentu dengan harapan akan menghasilkan sebuah keputusan yang terbaik. Hal lain yang tidak jauh berbeda dengan kerumitan yang dihadapi para siswa SMA saat hendak memilih program studi apa yang akan diambil pada saat melanjutkan pendidikannya di perguruan tinggi. Para siswa dihadapkan pada berbagai macam pertimbangan dan pilihan yang cukup rumit. Pertimbangan dari pihak siswa sendiri misalnya bidang studi yang dikuasai, minat siswa, cita-cita, prestasi ,nilai, akademik dan lingkungan pergaulan sedangkan pertimbangan yang datang dari sisi orang tua misalnya biaya pendidikan dan harapan orang tua terhadap anaknya. Beragam pertimbangan tersebut membuat siswa yang mengambil keputusan dalam memilih perguruan tinggi perasaan, ajakan teman dan ambisi orang tua saja, padahal semuanya itu tidak bisa dipakai sebagai tolak ukut yang tepat. Pendidikan merupakan bagian yang mempunyai peranan yang sangat penting dalam upaya mencerdaskan kehidupan bangsa terutama jika dikaitkan dengan upaya peningkatan mutu sumber daya manusia (SDM) karena sumber daya manusia yang berkualitas dapat meningkatkan martabat manusia itu sendiri (Sawaji, Hamzah, \& Taba, 2010).

Berdasarkan latar belakang yang diuraikan, maka penulis bermaksud untuk mengangkat masalah tersebut dengan mengabungkan berbagai referensi yang telah didapat sebagai suatu penelitian berjudul "Sistem Pendukung Keputusan Pemilihan Program Studi Perguruan Tinggi Menggunakan Metode Profile Matching Pada SMAN 13 Palembang". Sistem yang akan dibangun ini, diharapkan dapat membantu mengatasi masalah dari sistem yang saat ini belum memaksimalkan kinerja sekolah dengan baik.

\section{METODOLOGI PENELITIAN}

\subsection{Metode Penelitian}

Metode yang digunakan dalam penelitian ini adalah Research and Development (RnD). Penelitian dan pengembangan atau Research and Development (R\&D) adalah suatu pendekatan penelitian untuk menghasilkan suatu produk baru atau menyempurnakan produk yang sudah ada (Sukmadinata, 2006). Produk yang dihasilkan dapat berbentuk hardware maupun software. Produk software misalnya seperti program untuk pengolahan data, perpustakaan atau laboratorium, pembelajaran di kelas, ataupun modelmodel pendidikan, pembelajaran pelatihan, evaluasi, bimbingan, manajemen, dan lain sebagainya.

\subsection{Metode Pengumpulan Data}

Metode pengumpulan data yang digunakan dalam penelitian ini adalah sebagai berikut: 1) Wawancara. Dalam metode ini penulis mengumpulkan data penelitian dengan bertanya langsung kepada pihak yang bersangkutan yang dapat memberikan informasi yang dibutuhkan, 2) Observasi. Penulis melakukan pengamatan secara langsung di SMAN 13 Palembang tentang bagaimana proses pemilihan program studi untuk memilih perguruan tinggi yang sesuai dengan kriteria dan minat pada masin-masing siswa, dan 3) Kepustakaan. Mengumpulkan data dengan cara mencari dan mempelajari data-data dari buku-buku ataupun dari referensi lain yang berhubungan dengan penulisan laporan penelitian proposal. Buku yang digunakan penulis sebagai referensi, adapun metode yang digunakan penulis dalam merancang dan mengembangkan dapat dilihat pada daftar pustaka. 


\subsection{Metode Pengembangan Sistem}

Metode pengembangan sistem yang dipakai untuk membuat sistem pendukung keputusan pemilihan program studi perguruan tinggi pada SMAN 13 Palembang, penulis menggunakan Metode Prototype. Metode prototyping (Pressman, 2010) sebagai suatu paradigma baru dalam pengembangan sistem informasi manajemen, tidak hanya sekedar suatu evolusi dari metode pengembangan sistem informasi yang sudah ada, tetapi sekaligus merupakan revolusi dalam pengembangan sistem informasi manajemen. Selain itu, untuk memodelkan sebuah perangkat lunak dibutuhkan beberapa tahapan di dalam proses pengembangannya. Tahapan inilah yang akan menentukan keberhasilan dari sebuah software itu. Pengembang perangkat lunak harus memperhatikan tahapan dalam metode prototyping agar software finalnya dapat diterima oleh penggunanya. Dan tahapan-tahapan dalam prototyping tersebut adalah sebagai berikut: 1) Pengumpulan kebutuhan. Pengembang mendefinisikan format dan kebutuhan keseluruhan perangkat lunak, mengidentifikasikan semua kebutuhan, dan garis besar sistem yang akan dibuat, 2) Membangun prototyping. Membangun prototyping dengan membuat perancangan sementara yang berpusat pada penyajian kepada pelanggan (misalnya dengan membuat input dan contoh outputnya), 3) Evaluasi protoptyping. Evaluasi ini dilakukan oleh pelanggan apakah prototyping yang sudah dibangun sudah sesuai dengan keinginan pelanggan. Jika sudah sesuai maka langkah keempat akan diambil. Jika tidak, maka prototyping diperbaiki dengan mengulang langkah 1, 2, dan 3, 4) Mengkodekan sistem. Dalam tahap ini prototyping yang sudah disepakati diterjemahkan ke dalam bahasa pemrograman yang sesuai, dan 5) Menguji sistem. Setelah sistem sudah menjadi suatu perangkat lunak yang siap pakai, harus diuji dahulu sebelum digunakan. Pengujian ini dilakukan dengan White Box, Black Box, Basis Path, pengujian arsitektur dan lain-lain.

\subsection{Profile Matching}

Dalam proses profile matching (Kusrini, 2007) secara garis besar merupakan proses membandingkan antara kompetensi individu kedalam kompetensi program studi sehingga dapat diketahui perbedaan kompetensinya (disebut juga gap), semakin kecil gap yang dihasilkan maka bobot nilainya semakin besar yang berarti memiliki peluang lebih besar untuk siswa menempati posisi tersebut.Untuk menganalisis siswa yang sesuai dengan program studi tertentu dilakukan dengan metode profile matching, dimana dalam proses ini terlebih dahulu menentukan kompetensi (kemampuan) yang diperlukan oleh suatu program studi.

Setelah menentukan bobot nilai gap maka selanjutnya dikelompokan menjadi dua kelompok yaitu kelompok core factor dan secondary factor. Perhitungan core factor ditunjukkan menggunakan rumus:

Keterangan:

$$
N C F=\frac{\sum N C}{\sum I C}
$$

NCF : Nilai rata-rata core factor.

$\mathrm{NC}$ : Jumlah total nilai core factor.

IC : Jumlah item core factor.

Perhitungan factor secondary ditunjukkan menggunakan rumus:

Keterangan:

$$
N S F=\frac{\sum N S}{\sum I S}
$$

NSF : Nilai rata-rata secondary factor.

NS : Jumlah total nilai secondary factor.

IS : Jumlah item secondary factor.

Berdasarkan hasil perhitungan setiap kriteria diatas, selanjutnya dihitung nilai total berdasarkan persentase dari core factor dan secondary yang diperkirakan berpengaruh terhadap kinerja tiap-tiap profil. Rumus perhitungan bisa dilihat pada rumus:

$$
N S F=(60 \% \times N C F)+(40 \% \times N S F)
$$




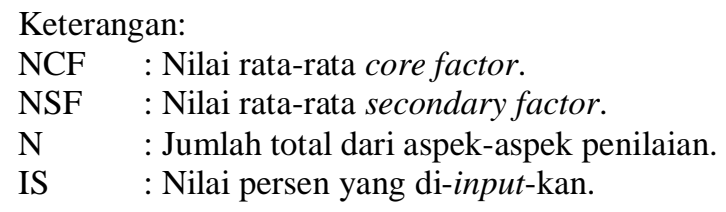

Hasil akhir dari proses profil matching adalah ranking dari kandidat yang diajukan. Setelah setiap kandidat mendapat hasil akhir, maka bisa ditentukan peringkat atau ranking dari kandidat berdasarkan pada semakin besarnya nilai hasil akhir sehingga semakin besar pula pemilihan suatu program studi perguruan tinggi.

\section{HASIL}

Berdasarkan hasil penelitian yang telah di lakukan pada SMAN 13 Palembang maka di dapatkan hasil akhir sebuah system yaitu "Sistem Pendukung Keputusan Pemilihan Program Studi Perguruan Tinggi Menggunakan Metode Profile Matching Pada SMAN 13 Palembang”.

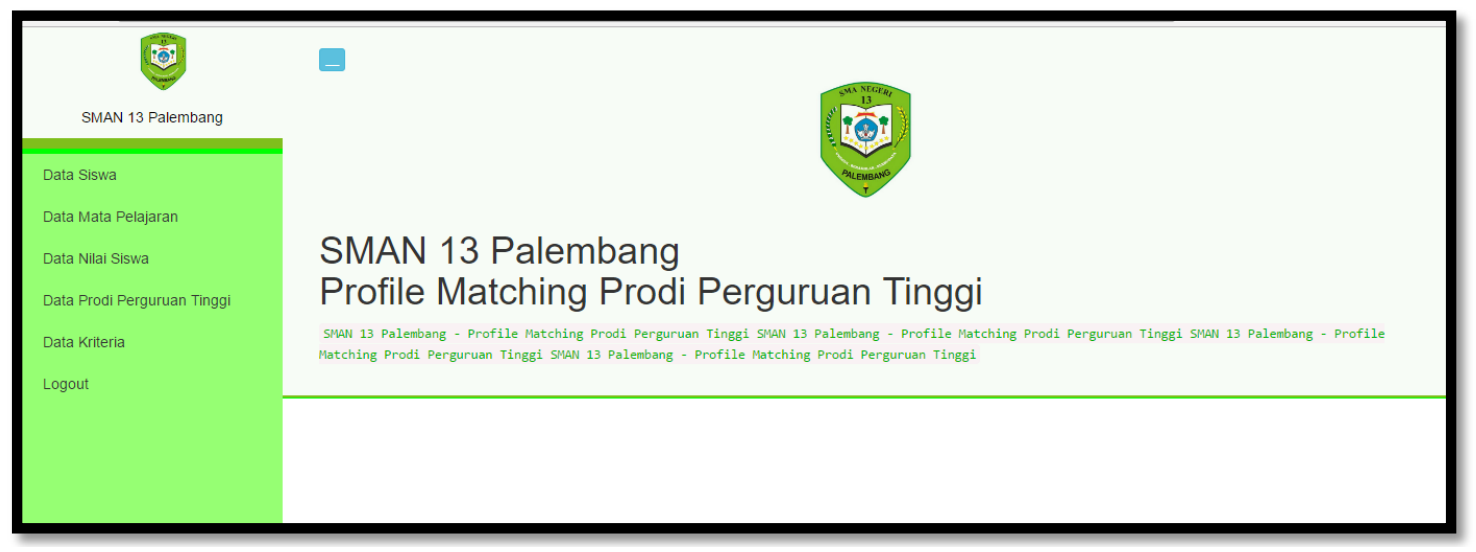

Gambar 1. Halaman Beranda Admin.

\subsection{Halaman Beranda Admin}

Halaman beranda merupakan halaman yang akan tampil ketika admin telah masuk ke dalam sistem. Di dalam halaman beranda admin ini terdapat beberapa menu yakni kelola data siswa, kelola data mata pelajaran, kelola data nilai siswa, kelola data program studi perguruan tinggi dan kelola data kriteria serta menu logout untuk keluar dari sistem. Proses yang terdapat pada setiap menu admin tersebut terdiri dari proses simpan dan edit (lihat gambar 1).

\subsection{Halaman Kelola Data Siswa}

Halaman kelola data siswa merupakan halaman yang berisikan proses penginputan data siswa oleh admin. Pada halaman ini admin dapat menambahkan data siswa yang akan dilakukan perhitungan profile matching-nya. Fields atau kolom yang harus diisi di dalam proses ini antara lain adalah data NIS siswa atau nomor induk siswa, nama siswa, alamat, tempat lahir, tanggal lahir, jenis kelamin dan nomor handphone siswa. Data-data tersebut harus diisi secara benar agar dapat masuk ke dalam tabel siswa dan ditampilkan dalam data tabel yang ada di samping form data siswa.

\subsection{Halaman Kelola Data Mata Pelajaran}

Halaman data mata pelajaran merupakan halaman yang digunakan oleh admin untuk meng-input-kan data mata pelajaran. Pada halaman ini admin harus mengisi data mata pelajaran yang dijadikan syarat perhitungan profile matching di SMA Negeri 13 Palembang. Data yang telah tersimpan selanjutnya akan disimpan ke dalam datatable yang ada di sebelah form data mata pelajaran.

\subsection{Halaman Niai Siswa}

Halaman data nilai siswa merupakan halaman yang berguna bagi admin untuk meng-input-kan data nilai siswa dari setiap mata pelajaran yang telah diinputkan sebelumnya pada master data pelajaran. Data 
ini merupakan data yang akan menentukan hasil rekomendasi dari prodi yang akan direkomendasikan kepada siswa. Admin terlebih dahulu memilih siswa yang akan di-input-kan nilainya, kemudian mengisi kolom nilai dari mata pelajaran yang sebelumnya telah di-input-kan di data master mata pelajaran. Nilai yang di-input-kan kemudian akan disimpan oleh sistem untuk nantinya digunakan oleh pimpinan dalam melakukan perhitungan profile matching.

\subsection{Halaman Kelola Prodi}

Halaman data prodi perguruan tinggi merupakan halaman data yang digunakan oleh admin untuk menambahkan data prodi perguruan tinggi. Pada halaman ini admin harus mengisi data prodi yang terdiri dari nama fakultas dan jurusan dan menekan tombol simpan. Data yang telah tersimpan selanjutnya akan disimpan ke dalam datatable yang ada di sebelah form data prodi perguruan tinggi.

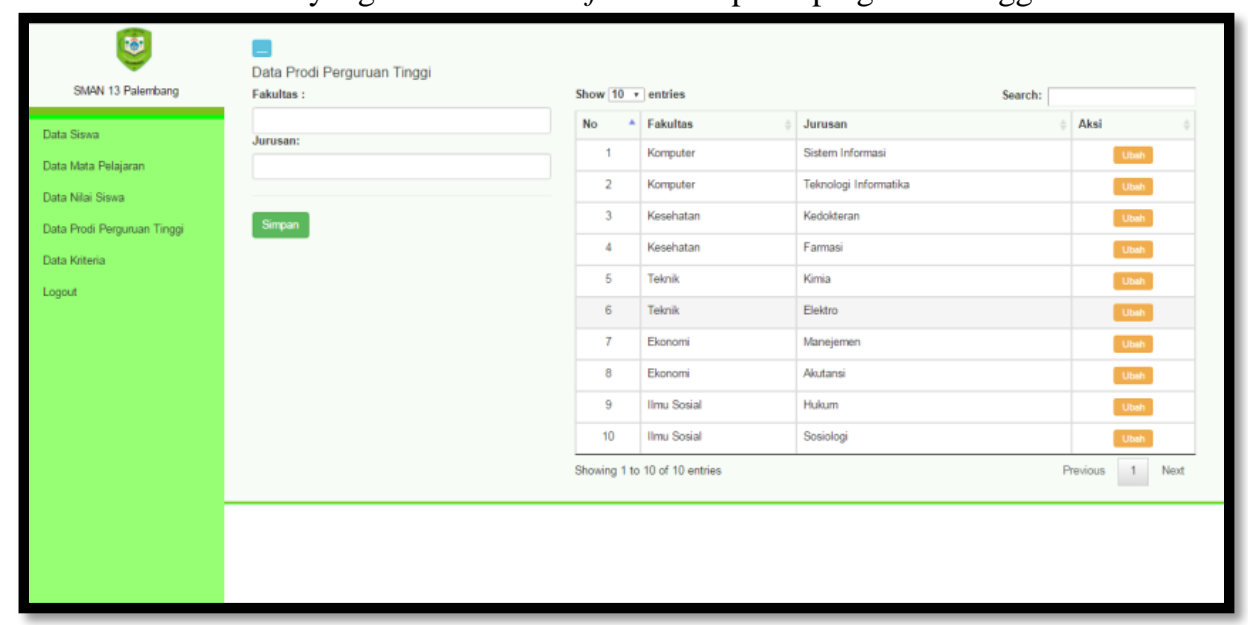

Gambar 2. Halaman Kelola Prodi.

\subsection{Halaan Kelola Kriteria}

Halaman data kriteria merupakan halaman data yang digunakan oleh admin untuk menambahkan kriteria profile matching yang akan digunakan sebagai indikator perhitungan profile matching. Pada halaman ini admin harus mengisi data kriteria yang terdiri nama prodi, mata pelajaran, syarat nilai, bobot nilai dan faktor yang terdiri dari secondary dan core factor. Secondary dan core factor terlebih dahulu harus dibagi proporsinya dan pada sistem yang dibuat pembagian proporsi core dan secondary factor masing masing 60 dan 40 persen. Artinya setiap kriteria yang di-input-kan harus memenuhi atau tidak boleh lebih dari proporsi yang telah ditetapkan. Data yang telah tersimpan selanjutnya akan disimpan ke dalam datatable yang ada di sebelah form data kriteria prodi perguruan tinggi. Data inilah nanti yang akan digunakan sebagai salah satu indikator perhitungan profile matching.

\subsection{Halaman Profile Matching}

Halaman data profile matching merupakan halaman data yang digunakan oleh pimpinan untuk melakukan perhitungan profile matching. Pada halaman ini pimpinan atau kepala sekolah hanya tinggal memilih nama siswa yang akan dilihat hasil perhitungan profile matching-nya. Perhitungan akan dilakukan oleh sistem secara otomatis ketika kepala sekolah atau pimpinan telah menekan tombol lihat rekomendasi.

\subsection{Halaman Rekomendasi}

Halaman data hasil rekomendasi merupakan hasil otomatis yang dilakukan oleh sistem ketika input-an siswa yang dipilih untuk dilakukan perhitungan telah masuk ke dalam sistem. Pada halaman ini terdapat hasil rekomendasi jurusan atau program studi berdasarkan hasil perhitungan profile matching dari beberapa kriteria yang dimasukkan. Setelah pimpinan memilih siswa yang akan dihitung nilai profile matching-nya sistem akan menampilkan dua buah hasil yakni hasil nilai mata pelajaran yang telah dikategorikan sebagai core dan secondary factor dan ranking rekomendasi prodi. Pada hasil analisa SPK Profile Matching terdapat keterangan apakah nilai siswa tersebut melewati nilai batas minimum yang ditetapkan. Apabila nilai siswa tersebut melebihi nilai minimum yang ditetapkan, maka sistem akan 
memberikan keterangan "ok". Selain itu nilai ranking rekomendasi diurutkan dari daftar prodi dengan nilai hasil perhitungan profile matching yang paling tinggi.

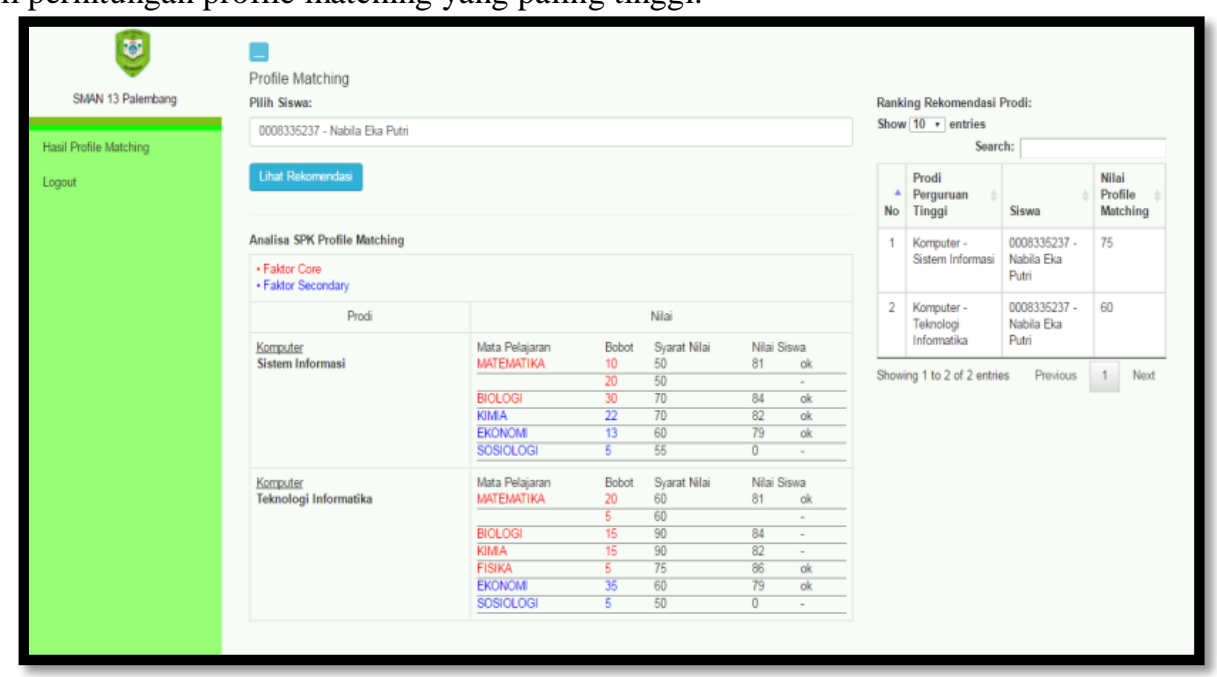

Gambar 3. Halaman Lihat Hasil Profile Matching Pimpinan.

\section{SIMPULAN}

Kesimpulan yang dapat diambil dari pelaksanaan Skripsi ini yang dilakukan dan hasil pembahasan yang diuraikan pada bab bab sebelumnya, maka dapat ditarik kesimpulan sebagai berikut :

1) Sistem yang dibangun untuk mengelola data siswa SMA Negeri 13 dapat digunakan oleh pihak sekolah dalam pengambilan keputusan untuk menentukan rekomendasi program studi bagi siswa.

2) Sistem ini dibangun menggunakan bahasa pemrogaman PHP dan MySQL sebagai bahasa pemrogaman untuk mengolah database.

3) Sistem SPK ini terdiri dari beberapa modul yakni kelola data siswa, kelola data mata pelajaran, kelola data nilai siswa, kelola data program studi program perguruan tinggi, kelola data kriteria, kelola data profile matching dan hasil rekomendasi.

\section{DAFTAR PUSTAKA}

Ariani, A., Abdillah, L. A., \& Syakti, F. (2013). Sistem pendukung keputusan kelayakan TKI ke luar negeri menggunakan FMADM. Jurnal Sistem Informasi (SISFO), 4(5), 336-343.

Kusrini. (2007). Konsep dan Aplikasi Sistem Pendukung Keputusan. Yogyakarta: Andi Offset.

Murti, T., Abdillah, L. A., \& Sobri, M. (2015). Sistem Penunjang Keputusan Kelayakan Pemberian Pinjaman pada PT Triprima Finance Palembang dengan Metode Fuzzy Tsukamoto. Paper presented at the Seminar Nasional Inovasi dan Tren 2015 (SNIT2015), Kalimalang, Jakarta.

Nufus, W. (2013). Sistem Pendukung Keputusan Pemilihan Program Studi pada Perguruan Tinggi Melalui Jalur SNMPTN pada SMA N 16 Semarang. Sarjana Komputer Skripsi, Universitas Dian Nuswantoro, Semarang. Retrieved from http://eprints.dinus.ac.id/12717/

Pressman, R. S. (2010). Software Engineering: A Practitioner's Approach (7th ed.). New York, US: McGraw-Hill.

Putra, A. J., Abdillah, L. A., \& Yudiastuti, H. (2016). Penentuan Sekolah Dasar Negeri Terbaik Kota Palembang dengan Metode Weighted Sum Model (WSM) dan Weighted Product Model (WPM) Menggunakan Visual Basic.Net 2015. Paper presented at the Seminar Nasional Penelitian Ilmu Komputer Ke-1 (SENTIKOM2016), Palembang.

Sawaji, J., Hamzah, D., \& Taba, I. (2010). Pengambilan keputusan mahasiswa dalam memilih perguruan tinggi swasta di Sulawesi Selatan. E-Journal Program Pascasarjana Universitas Hasanuddin.

Sukmadinata. (2006). Metode Penelitian. Bandung: Rosdakarya.

Surbakti. (2002). Sistem Pendukung Keputusan. Institut Teknologi Sepuluh November (ITS). Surabaya.

Umami, P., Abdillah, L. A., \& Yadi, I. Z. (2014). Sistem penunjang keputusan pemberian beasiswa bidik misi. Paper presented at the Konferensi Nasional Sistem Informasi (KNSI), STMIK Dipanegara Makassar, Sulawesi Selatan. 